\title{
Multi-site evaluation of the rearing performances of 5 wild populations of European sea bass (Dicentrarchus labrax)
}

\author{
Marc Vandeputte ${ }^{\mathrm{a}, \mathrm{b}, *}$, Romain Garouste ${ }^{\mathrm{a}}$, Mathilde Dupont-Nivet ${ }^{\mathrm{b}}$, Pierrick Haffray ${ }^{\mathrm{c}}$, Alain Vergnet ${ }^{\mathrm{a}}$, \\ Hervé Chavanne $^{d}$, Stanislas Laureau ${ }^{\mathrm{e}}$, Tetsuzan Benny Ron ${ }^{\mathrm{f}, 1}$, Glen Pagelson ${ }^{\mathrm{g}}$, Carlos Mazorra ${ }^{\mathrm{h}}$, \\ Rémi Ricoux ${ }^{i}$, Pedro Marques ${ }^{j}$, Marta Gameiro ${ }^{j}$, Béatrice Chatain ${ }^{a}$
}

\author{
a Ifremer, UMR110 INTREPID, Chemin de Maguelone, F-34250 Palavas-les-Flots, France \\ ${ }^{b}$ INRA, UMR1313 GABI, F-78350 Jouy-en-Josas, France \\ ${ }^{c}$ Sysaaf, Station INRA LPGP, F-35042 Rennes, France \\ d Istituto Sperimentale Lazzaro Spallanzani, I-26027 Rivolta d'Adda (CR), Italy \\ ${ }^{e}$ Ecloserie Marine de Gravelines, F-59820 Gravelines, France \\ ${ }^{\dagger}$ National Center for Mariculture, Israel Oceanographic and Limnological Research, Eilat 88112, Israel \\ ${ }^{9}$ Ardag Ltd, P.O. Box 1742, Eilat 88116, Israel \\ h Tinamenor S.L., Marisma de Pesués 7, 39548 Pesués, Cantabria, Spain \\ iLes Poissons du Soleil, F-34540 Balaruc les Bains, France \\ j Viveiro Vilanova, Foros de Galeado, 7645-073Vila Nova de Milfontes, Portugal \\ ${ }^{1}$ Present address: HNFAS, CTAHR, University of Hawaii at Manoa, Honolulu, HI 96822 USA.
}

*: Corresponding author : Marc Vandeputte, tel.: + 33467130407 ; email address : marc.vandeputte@jouy.inra.fr

\begin{abstract}
:
Sea bass is a major species in Mediterranean aquaculture, but has a distribution area ranging from North Atlantic to South Mediterranean, with a population structure previously revealed by population genetics. To test the farming performances of wild sea bass populations, we produced a partial diallel cross mating scheme, using sires originating from North Atlantic (NAT), South Atlantic (SAT), West Mediterranean (WEM), North-East Mediterranean (NEM) and South-East Mediterranean (SEM). Fifteen sires per origin were mated in a full-factorial design using artificial fertilization with 9 NAT dams and 17 WEM dams, producing 10 population crosses and 1950 potential full-sib families. All fish were reared together, then tagged at an average weight of $20 \mathrm{~g}$ and distributed to four different sites (1800 fish per site). They were grown to an objective of $200 \mathrm{~g}$ mean weight, where 737 to 775 fish were slaughtered in each site, and their parentage was recovered using 6 to 7 microsatellite loci, resulting in $98.9 \%$ unique assignments. All populations had similar growth rates until tagging size $(20 \mathrm{~g})$, but differences appeared later on. No heterosis appeared for growth rate, and genotype by environment interaction $(\mathrm{GXE})$ at the population level was limited, with a significant re-ranking only in one rearing site, while strong GxE for growth rate was observed within populations. Populations were different in shape, muscular fat content, carcass yield, but not in fillet yield. In general, heterosis was absent and GxE was very limited between populations. No "ideal" population combining all favourable traits was identified. Differences between extreme populations ranged between 3 and $49 \%$ of the mean, depending on the traits. Interestingly, in almost all cases, these differences were within the reach of one generation of intense (5\%) phenotypic selection.
\end{abstract}




\section{Highlights}

We studied additive strain effects, heterosis, GxE interactions and within population additive genetic variance for rearing performances of 5 wild populations of European sea bass in a multi-site evaluation using molecular pedigrees. Most traits were under additive genetic control with no heterosis and limited genotype by environment interactions at the population level. - No "ideal" population combining all favourable traits was identified, but interestingly, for almost all traits, differences between extreme populations $(3-49 \%$ of the mean) were within the reach of one generation of intense $(5 \%)$ phenotypic selection.

Keywords : European sea bass ; Dicentrarchus labrax ; selective breeding ; population ; growth ; processing yields ; genotype by environment interaction 


\section{Introduction}

For over seventy years, genetic improvement has become one of the two mainstays that, together with husbandry, have improved agricultural production, both in plant and animal fields. For main crops (maize, wheat, soy bean, etc.) and livestock farming (chicken, cattle, pigs, etc.), the organization of the production chain has reached a high level of specialization, dividing sectors between breeders, growers, processors and distributors. In aquaculture, the first family-based breeding programme was initiated in Norway in 1972 (Gjedrem, 2010), but the general picture is that the use of genetically improved stocks, albeit increasing, remains low in most species (Gjedrem et al., 2012).

Contrary to terrestrial livestock, most farmed fish species were domesticated very recently (Teletchea and Fontaine, 2012), while wild populations are still available. Thus, the base populations for a selective breeding programme can be chosen from the existing wild stocks, which may differ for commercially important traits such as growth rate (e.g., Conover et al., 1997 for growth in striped bass, Marcil et al., 2006 for shape in cod). As a matter of fact, several important fish breeding programmes have started with a strain-comparison experiment (see Gunnes and Gjedrem, 1978 for the Norwegian salmon breeding programme or Bentsen et al., 1998 for the GIFT tilapia breeding programme). In such comparisons, it is important to use extemporaneous growing of the different strains, and it may be important to test for different line crosses in case heterosis would be significant, although in many cases it appears to be low in crosses between non inbred fish populations (Gjerde and Refstie, 1984; Bentsen et al., 1998). It may also be relevant to investigate potential genotype by environment interaction (GxE), and this is especially true in the European sea bass (Dicentrarchus labrax L.) where it has been shown to be very high on growth rate at the family level (Dupont-Nivet et al., 2010).

The European sea bass is one of the two major species of Mediterranean aquaculture, and has been shown to exhibit large within population genetic variability for growth (Dupont-Nivet et al., 2008; Vandeputte et al., 2009). As many farmed populations of sea bass are in the very first generations of captive breeding, the question of evaluating wild populations for their adequacy to farming is timely. From a population genetics point of view, there is a strong difference between Mediterranean and Atlantic populations of sea bass, related to a natural barrier in the Alboran sea in South-eastern Spain (Naciri et al., 1999). Within the Mediterranean, there is a clear cut between East and West populations, and the populations seem very homogeneous in the Western region, while quite different in the Eastern part 
(Bahri-Sfar et al., 2000; Castilho and Ciftci, 2005).

In the present study, we investigated the performance of 5 natural populations of sea bass in a partial diallel design with 5 sire populations and 2 dam populations. This was done using a common garden methodology, with all progenies mixed since incubation, the parentage and the populations of origin being recovered a posteriori by genotyping of microsatellite markers. Fish were distributed amongst 4 different growout sites to test for GxE.

\section{Materials and methods}

\subsection{General experimental design}

Wild European sea bass were collected from five different areas widely covering the distribution of the natural populations, North Atlantic (NAT), South Atlantic (SAT), West Mediterranean (WEM), North-East Mediterranean (NEM) and South-East Mediterranean (SEM), to be used as broodstock fish. Males were collected from all five populations, while females were available only from the NAT and WEM populations. Females were transported live to the Ifremer station of Palavas-les-Flots (France) while sperm from the sires was cryopreserved onsite. A full factorial mating of 15 sires per origin and 9 NAT and 17 WEM dams was done by artificial fertilization at Palavas-les-Flots, France. After equalization of fertilized egg quantity among the ten population crosses, a single batch of eggs was sent for larval and juvenile rearing to Viveiro Vilanova (Vila Nova de Milfontes, Portugal). At $1.6 \mathrm{~g}$ mean weight, 3000 fish were air-shipped to Ardag (Eilat, Israel) where they were reared in an indoor raceway, while the remainder of the same batch was reared in a tank in Portugal (see figure 1). Upon reaching ca. $20 \mathrm{~g}$ mean weight, 1800 fish in Israel and 5400 fish in Portugal were measured, individually tagged and DNA sampled. The 1800 Ardag fish were thereafter transferred to a sea cage in the Red sea, and among Vila Nova fish, 1800 were sent to Tinamenor/ADSA (Canary Islands, Spain), for on-growing in circular tanks fed with stable temperature well and sea water, 1800 were sent to Les Poissons du Soleil (Balaruc les Bains, France) for on-growing in square tanks fed by fluctuating temperature lagoon and well water, while 1800 remained in Portugal for on-growing in a tidal earthen pond. The pedigree of the fish (hence their population cross of origin) was recovered by genotyping of microsatellites. At the date where the projected growth of the fish reached $c a .200 \mathrm{~g}$, an objective of 800 fish (80 per population cross) per rearing site was slaughtered and submitted to a final biometry protocol. This happened at different ages (from $377 \mathrm{dpf}$ in Israel to $551 \mathrm{dpf}$ in Portugal - see 
figure 1) due to differences in the rearing environments (especially temperatures).

\subsection{Broodstock collection}

NAT fish were caught in the surroundings of Boulogne sur Mer in 2004 and 2005, and along the coasts of Brittany (Etel and Quiberon). Seventy-one females were kept in a broodstock tank in Ifremer in Palavas, while the sperm of 17 males was cryopreserved according to Fauvel et al. (1998) .

SAT fish were wild broodstock collected from Rio Mira in Portugal, among which 16 males were collected for sperm cryopreservation according to the method by Sansone et al.(2002). Wild WEM fish were collected from the Gulf of Lions, close to Perpignan, Palavas and La Ciotat. 44WEM females and 41 WEM males were kept as broodstock in Palavas. The males were stripped and their sperm cryopreserved either according to Fauvel et al. (1998) or using CryoFish $^{\mathrm{TM}}$ (Haffray et al., 2008). NEM fish were collected from the Beymelek Lagoon during 2005, and sperm was cryopreserved from 30 using Sansone et al. (2002) methodology. 120 wild SEM sea bass (presumably yearlings, 30-50 g) were captured during 1995 along the Egyptian coast of the Mediterranean Sea. Some of the fingerlings were collected from the brackish-water Lake 'Edku' located in the estuarine area of the Nile River and the remainder from the coastalwaters of the Mediterranean Sea near Port-Said (Gorshkov etal., 2004). These fish were transported to IOLR (Eilat, Israel), raised separately under controlled conditions, and used as broodstock once adult. The first generation (unselected) progeny of these parental fish were used as SEM broodstock for the present experiment, and 21 males were chosen for sperm cryopreservation (Sansone et al., 2002). Sperm quality may be impaired during long cryogenic storage as shown in the striped bass (Kerby, 1983). However, possible effects of sperm quality on fertilization rates at the population level were corrected later on by equalizing fertilized egg quantities at $48 \mathrm{~h}$ post-fertilization.

DNA samples were taken from all males and females for further parentage assignment.

\subsection{Production of the experimental progenies}

Females were checked for maturation status by biopsy, and the females that had reached the appropriate maturation stage (15 NAT and 24 WEM) were hormonally injected (LHRHa, $\left.10 \mu \mathrm{g} . \mathrm{kg}^{-1}\right)$. The stripping of each female was done 72, h post-injection. Eggs from 9 NAT females and 17 WEM females were collected at that time. The eggs were mixed in nearly equal proportion within each origin: $250 \mathrm{ml} /$ female for all NAT females except one $(180 \mathrm{ml})$ 
and $150 \mathrm{ml} /$ female for WEM females, thus producing one pool of $2180 \mathrm{ml}$ of NAT eggs, and one pool of $2550 \mathrm{ml}$ of WEM eggs.

The pool of WEM eggs was sub-sampled to produce 75 aliquots of $30 \mathrm{ml}$ of eggs. Each aliquot was individually fertilized using the sperm of 15 males from each geographical origin (1275 potential families: 17 females x 75 males) The pool of NAT eggs was also sub-sampled to produce 75 aliquots of $25 \mathrm{ml}$ of eggs which were also fertilized with the sperm of 15 males from each geographical origin (675 potential families: 9 females $\times 75$ males) The fertilized eggs were mixed by male $\mathrm{x}$ female origin (10 population crosses) and incubated in 10 different incubators. After 48 hours of incubation, they were all mixed in equal volumes leading to 2.6 million fertilized eggs with equal representation of each population cross. At 4 days post-fertilization (dpf), newly hatched larvae were transferred for larval rearing to Viveiro Vila Nova (Vila Nova de Milfontes, Portugal).

\subsection{Rearing of the progenies}

Larval rearing was done in one $6 \mathrm{~m}^{3}$ tank starting with 1090000 fish at $7 \mathrm{dpf}$. The temperature gradually increased from 16 to $20^{\circ} \mathrm{C}$ at $40 \mathrm{dpf}$, where the fish were transferred to a $15 \mathrm{~m}^{3}$ nursery tank. Fish without swimbladder were removed at $86 \mathrm{dpf}$, and temperature was kept constant around $20^{\circ} \mathrm{C}\left(19-21^{\circ} \mathrm{C}\right)$ until $127 \mathrm{dpf}$. At $111 \mathrm{dpf}, 3000$ fish of $1.6 \mathrm{~g}$ mean weight were sent to Ardag (Eilat, Israel) where they were reared in an indoor tank of $10 \mathrm{~m}^{3}$ at temperatures between 24 and $29^{\circ} \mathrm{C}$.

The fish traits measurements indexed according to the ATOL fish trait ontology (http://www.atol-ontology.com/index.php/en/les-ontologies-en/visualisation-en, Golik et al., 2012). At $187 \mathrm{dpf}$ the fish in Israel had reached a mean weight of $24 \mathrm{~g}$, and 1800 of them were randomly chosen, individually weighed (body weight, ATOL:0000351, nearest $0.1 \mathrm{~g}$ ) and measured (standard length, ATOL:0001659, nearest mm), PIT-tagged and fin-clipped for further DNA extraction. At $216 \mathrm{dpf}$, the fish in Portugal had reached a mean weight of $20 \mathrm{~g}$, and 5400 of them ( 3 batches of 1800) were submitted to the same sampling and tagging procedure. Following tagging, each of the three batches from Portugal was kept in a $9 \mathrm{~m}^{3}$ tank until it was sent to the fish growout sites (Portugal, Canary Islands, France).

In Israel, the fish tagged at $187 \mathrm{dpf}$ were first reared in a $10 \mathrm{~m}^{3}$ indoor tank, and then transferred to a sea cage at $219 \mathrm{dpf}$, upon reaching $40 \mathrm{~g}$ mean weight. The cage volume was $60 \mathrm{~m}^{3}$, and the fish were grown until harvest, while rearing temperatures were progressively decreasing from 29 to $20^{\circ} \mathrm{C}$. The fish were grown on a feed containing $46 \%$ protein and $22 \%$ 
crude fat (Raanan Fish Feed Ltd, Israel). Upon harvesting at $377 \mathrm{dpf}$, the fish reached an average weight of $248 \mathrm{~g}$ and they were transferred to an indoor tank were they were subjected to the final biometry protocol (see below).

In Canary Islands, the fish arrived from Portugal at $242 \mathrm{dpf}$. They were put in a $15 \mathrm{~m}^{3}$ circular concrete tank which was provided with well water at a constant $22^{\circ} \mathrm{C}\left(21.0-22.8^{\circ} \mathrm{C}\right)$. At 399 $\mathrm{dpf}$, the water inlet was switched to seawater (temperature $18.8-20.1^{\circ} \mathrm{C}$ ). The fish were grown on Skretting L Power pellets (49\% protein and 23\% lipid) from 242 to360 dpf, and on Skretting D Power pellets (48\% protein, 21\% lipids) from 361 to 446 dpf. The fish were harvested at $446 \mathrm{dpf}$ when they had reached a mean weight of $144 \mathrm{~g}$ and were subjected to the final biometry protocol.

In France, the fish arrived from Portugal $237 \mathrm{dpf}$ and were put in a $20 \mathrm{~m}^{3}$ square concrete tank which was provided with a mixture of well and lagoon water (salinity 37-42 ppt, temperature $15-27{ }^{\circ} \mathrm{C}$ ). The fish were grown on a feed containing $47 \%$ protein and $18 \%$ lipid (Biomar). At $524 \mathrm{dpf}$ the fish had reached a mean weight of $199 \mathrm{~g}$ and were subjected to the final biometry protocol.

In Portugal, the fish stayed in the rearing tank until $334 \mathrm{dpf}$, then transferred ontoa $540 \mathrm{~m}^{2}$, $0.8 \mathrm{~m}$ depth earthen pond. The fish were grown on Dibaq OVN feedr. They were transferred back onto a concrete tank at $547 \mathrm{dpf}$ when they had reached a mean weight of $151 \mathrm{~g}$, and were subjected to the final biometry protocol at $551 \mathrm{dpf}$.

\subsection{Parentage assignment}

The 7,200 sea bass were assigned to their parents using microsatellite markers analysis by Istituto Spallanzani (Rivolta d'Adda, Italy). Seven markers were used, Dla016, Dla020, Dla105, Dla116, Dla119, Lab13, and occasionally Lab3 on progenies still having more than one possible parental pair with the first six markers (Chistiakov et al., 2004; Ciftci et al., 2002; Garcia De Leon et al., 1995). Genomic DNA was extracted using AB6100 (Applied Biosystems) with Nuc-Prep (Applied Biosystems) chemistry. Amplification was performed in a $20 \mu \mathrm{l}$ polymerase chain reaction (PCR) mixture containing $25 \mathrm{ng}$ of genomic DNA, $2.0 \mu \mathrm{l}$ PCR buffer, $1.2 \mu \mathrm{IgCl}_{2}, 0.4$ units Amplitaq Gold (Applied Biosystems), $1.25 \mathrm{mM}$ dNTPs mix (Applied Biosystems) and 10pmol for each primer. The reverse primers were 5' endlabelled with FAM, NED and VIC fluorochromes. The samples were amplified on a Thermal Cycler (Applied Biosystems 9600 Geneamp PCR System) according to the following protocol: 10min initial denaturation at $95^{\circ} \mathrm{C}$ (hot start) followed by 30 cycles of $1 \mathrm{~min}$ at $94^{\circ} \mathrm{C}, 30 \mathrm{~s}$ at $55^{\circ} \mathrm{C}, 1 \mathrm{~min}$ at $72^{\circ} \mathrm{C}$ and extension at $72^{\circ} \mathrm{C}$ for $60 \mathrm{~min}$. The polymorphism was 
screened in a capillary sequencer (Applied Biosystems 3100).

The parentage assignment was established with the VITASSIGN program (Vandeputte et al., 2006), with two allelic mismatches tolerated, resulting in 7120 of the 7200 fish (98.9\%) being assigned to a unique parental pair. Among the unassigned fish, $41(0.6 \%)$ did not provide good DNA amplification, $35(0.5 \%)$ were assigned to two or more parent pairs, and only 4 $(0.05 \%)$ were not assigned to any parent pair. This is indicative of a low genotyping error rate and of a good assignment power of the marker set used (Vandeputte et al., 2006). The number of fish per cross at tagging was rather unbalanced, ranging from 299 in the ${ }^{\lambda} \mathrm{WEMx}+\mathrm{WEM}$ cross to 1660 in the ${ }^{\lambda} \mathrm{NATx}+\mathrm{WEM}$ cross (see Guinand et al., submitted, for more details)

\subsection{Final biometry protocol at harvest}

At harvest, we intended to slaughter 800 fish ( 80 for each of the sire origin $\mathrm{x}$ dam origin crosses) and leave the remainder for use as future brood fish in the farms. Using the information from the parentage assignment data, we randomly selected the 80 fish per cross among the ones identified, using a stratified sampling strategy where the cross of each fish entering the process was identified from its individual tag, and the fish was sampled or not depending on whether the proportion of fish to sample in this cross exceeded or not a random number drawn in a $\mathrm{U}[0,1]$ uniform distribution. In some cases, due to unrecorded mortalities or to insufficient numbers of fish per cross, less than 80 fish were available for sampling for some crosses.

The fish were fasted for 2 days prior to harvest. On harvest day, all fish were tranquilized with $0.1 \mathrm{ml} / 1$ 2-phenoxyethanol in the tank. They were captured in small numbers and deeply anaesthetised using $0.3 \mathrm{ml} / \mathrm{l}$ 2-phenoxyethanol. Then, their tag was read and they were weighed (ATOL:0000351) to the nearest $0.1 \mathrm{~g}$, and measured (ATOL:0001659) to the nearest $0.1 \mathrm{~mm}$ with an electronic ruler (Elgo Electric, Germany). The muscle fat content (ATOL:0001663) was then estimated as the mean of four measurements (two on each side) with at Fish Fat Meter (FM692, Distell, UK). Then based on its cross of origin (known after tag reading) and on a random sampling process, the fish was chosen either to stay as future broodstock, in which case it was returned to a holding tank with sea water, or to be slaughtered. Slaughtered fish were first killed with an excess dose of 2-phenoxyethanol (>0.6 $\mathrm{ml} / \mathrm{l})$. Then, they were dissected, their sex was identified by visual inspection of the gonads, and the following parts were weighed to the nearest 0.1g: carcass (ATOL:0001057), liver (ATOL:0000459), digestive tract (including peri-visceral fat - ATOL:0001557), gonads, dorsal fat (ATOL:0001058). Then, the fish were de-headed, and manually filleted on the left side. 
Head (ATOL:0001545), left fillet (ribs and skin on) and half-carcass were weighed to the nearest $0.1 \mathrm{~g}$. Total fillet weight was estimated as twice the weight of the left fillet. Finally, the spine was visually inspected, and scored for spine deformities (normal, scoliosis, cyphosis, lordosis). Additionally, in France and Portugal, some fish suffered from nephrocalcinosis, so the kidney was dissected and presence/absence of the disease was empirically scored for each fish.

\subsection{Statistical analyses}

The dataset of fish slaughtered at harvest was scrutinized for errors in measurements, detection of outliers, incompatibilities between length and weight data, differences between sum of parts of fish and live or carcass weight. Fish, which could not be assigned to a single parental pair were also excluded from the analysis. This resulted in 719 usable records at harvest (slaughtered fish) in Israel, 752 in Canary Islands, 732 in France and 683 in Portugal. Growth was studied both as $\ln$ (body weight) and as TGC (Thermal growth coefficient ATOL:0001661). TGC was calculated as follows:

$T G C=\frac{W_{v}^{\frac{1}{3}}-W_{t}^{\frac{1}{3}}}{\sum_{i=t}^{n}\left(T_{i}^{\circ}-10\right)} \times 1000$

Where $W_{n}$ is the final weight at day $n, W_{t}$ is the initial weight at tagging, and $\sum_{i=t}^{n}\left(T_{i}^{\circ}-10\right)$ is the sum of day-degrees (base $10{ }^{\circ} \mathrm{C}$ ) from tagging to final weight. The models used (SASMixed) were the following:

$Y_{i-q}=\mu+F_{i}+S_{j}+N_{k}+M_{l}+P_{m}+D_{n}+P D_{m n}+s_{o(m, n)}+d_{p(m, n)}+\varepsilon_{i-q}[$ Model 1.1]

Where $Y_{i-q}$ is the performance of the $q^{\text {th }}$ individual, $\mu$ is the population mean, $F_{i}$ is the fixed effect of farm $i$ ( $i=1-4$ at slaughter, $i=1-2$ at tagging), $S_{j}$ is the fixed effect of $\operatorname{sex}(j=1$ for males, 2 for females), $N_{k}$ is the fixed effect of nephrocalcinosis ( $k=0$ for sane, 1 for affected), $M_{l}$ is the fixed effect of spine deformities ( $l=0$ for sane, 1 for affected), $P_{m}$ is the fixed effect of paternal population $m(m=1-5), D_{n}$ is the fixed effect of maternal population $n(n=1,2)$, $P D_{m n}$ is the fixed interaction term between paternal population $m$ and maternal population $n$, $s_{o(m, n)}$ is the random effect of sire $o$ nested within paternal population $m$ and maternal population $n, d_{p(m, n)}$ is the random effect of dam $p$ nested within paternal population $m$ and maternal population $n$, and $\varepsilon_{i-q}$ is the random residual. 
When heterosis was not present, a second model was used to test for GxE interaction at the population level:

$$
Y_{i-q}=\mu+F_{i}+S_{j}+N_{k}+M_{i}+P_{m}+D_{n}+F P_{i m}+F D_{i m}+s_{Q(i, m)}+d_{p(i, n)}+\varepsilon_{i-q}[\text { Model }
$$

\section{$1.2]$}

Where all effects were the same as in model 1.1 except the following: $F P_{i m}$ which is the fixed interaction term between site $i$ and paternal population $m, F D_{i n}$ which is the fixed interaction term between site $i$ and maternal population $n, s_{o(i, n)}$ which is the random effect of sire $o$ nested within paternal population $m$ and site $i, d_{p(i, n)}$ which is the random effect of dam $p$ nested within dam population $n$ and site $i$.

When neither heterosis nor GxE were present, a third model was used to estimate paternal and maternal population effects:

$$
Y_{i j k \text { mmopq }}=\mu+F_{i}+S_{j}+N_{k}+M_{l}+P_{m}+D_{m}+s_{\sigma(m)}+d_{p(n)}+\varepsilon_{i j k l m n o p q} \text { [Model 1.3] }
$$

Where all effects are the same as before except $s_{o(m)}$ which is the random effect of sire $o$ nested within paternal population $m$, and $d_{p(n)}$ which is the random effect of dam $p$ nested within maternal population $n$.

When GxE was present, population effects were analysed within site with :

$$
Y_{i-q}=\mu+S_{j}+N_{k}+M_{i}+P_{m}+D_{n}+s_{o(m)}+d_{p(n)}+\varepsilon_{i-q} \text { [Model 1.4] }
$$

Continuous traits other than growth such as shape (measured by $K=10^{5} \cdot \frac{B \mathrm{~W}}{B L^{8}}$ ), muscle fat and body compartments were also tested relative to the size of the fish, taken into account by $\ln (B W)$, in ANCOVA models in SAS-Mixed. In such cases, the model sequence was as follows:

$$
\begin{aligned}
& Y_{i j k \text { mnnopq }}=\mu+F_{i}+S_{j}+N_{k}+M_{l}+a \cdot \ln \left(B W_{q}\right)+P_{m}+D_{n}+b_{i} \cdot \ln \left(B W_{q}\right)+ \\
& c_{m} \cdot \ln \left(B W_{q}\right)+e_{n} \cdot \ln \left(B W_{q}\right)+s_{o(m)}+d_{p(n)}+\varepsilon_{i-q}
\end{aligned}
$$

[Model 1.1a]

Where $a$ is the regression coefficient of $Y$ on $\ln (B W), B W_{q}$ is the weight of individual $q, b_{i}$ is the partial regression coefficient of $Y$ on $\ln (B W)$ within site $i, c_{m}$ is the partial regression coefficient of $Y$ on $\ln (B W)$ within paternal strain $m$ and $e_{n}$ is the partial regression coefficient of $Y$ on $\ln (B W)$ within maternal strain $n$. When all $b_{i}, c_{m}$, and $e_{n}$ were not significantly different from zero (heterogeneity of slopes test, see Littell et al., 1991), we used Models 1.1b [=Model 1.1 including $a \cdot \ln \left(B W_{q}\right)$ ], 1.2b [=Model 1.2 including $\left.a \cdot \ln \left(B W_{q}\right)\right], 1.3 \mathrm{~b}$ [=Model 1.3 
including $\left.a \cdot \ln \left(B W_{q}\right)\right]$ and $1.4 \mathrm{~b}\left[=\right.$ Model 1.4 including $\left.a \cdot \ln \left(B W_{q}\right)\right]$ in the same way as we did for Models 1.1 to 1.4.

For body parts, first all data were studentized (mean=0, $\mathrm{SD}=1$ ) within site before treatment. Then, $Y$ was calculated as the natural logarithm of the weight of the part studied, so all parts weights were studied in a Log-Log analysis, and $a$ represented the allometric coefficient of the body part studied relative to body weight. Therefore, all effects were residuals from the allometric relationship of the weight of the body part to the whole body weight, and a positive effect was representative of a higher yield of the given body part (higher weight of the body part relative to body weight), while a negative effect was representative of a lower yield. For body parts, non-studentized log-transformed data were also used, exclusively to test the site effect (which, by construction, cannot be tested with data studentized within site).

For significance tests in all models, we used the Satterthwaite's approximation for degrees of freedom, using the relevant combination of random effects as a residual. Multiple comparisons of Least Square means were performed with Tukey's HSD.

Differences between populations were mostly studied as the differences of least square means between the offspring of the different sire populations, as heterosis was never significant on the traits studied. Differences between dam populations were also investigated, but mostly as a confirmation of the effect seen on sire populations. When comparing sire populations, the difference between offspring groups only reveals half of the additive population value, as only sires differ between the offspring groups tested, which share the same dams. Therefore, the population additive effect reported was estimated as twice the difference between sire population offspring groups.

For all traits, the within-strain heritability of the trait was estimated from the variance components from the appropriate model including sire population, dam population, sex and when needed spine deformities and nephrocalcinosis as fixed effects, and a regression on ln $(B W)$ if appropriate, and an animal random genetic effect which was fitted in VCE6.0 (Groeneveld et al., 2008) under the hypothesis that the within population heritability was the same in all populations, as in any case we did not have enough sires per population $(n=15)$ to test for different heritabilities among populations. For growth rate (TGC) in which genotype by environment interactions were detected at the population level, we additionally considered TGC in the four different sites as different traits to estimate genetic correlations of the random animal genetic effect between sites, to test for genotype by environment interaction within populations

\section{Results}




\subsection{Basic grow-out parameters}

The basic data of the fish in all sites is shown in Table 1. The age at slaughter varied from 377 dpf in Israel to $551 \mathrm{dpf}$ in Portugal, mostly reflecting differences in rearing temperature (from $18.2^{\circ} \mathrm{C}$ in Portugal to $24.4^{\circ} \mathrm{C}$ in Israel). The thermal growth coefficient (TGC) was highest in Israel, very similar in France and Portugal, and lowest in Canary Islands. However, the slaughter weights were quite different amongst all sites, ranging from $144 \mathrm{~g}$ in Canary Islands to $248 \mathrm{~g}$ in Israel. Only French fish were slaughtered at the planned $200 \mathrm{~g}$ mean weight. This reflects both the difficulties to adjust planned growth curves with intermediate samplings and the inherent difficulties to plan sufficiently in advance the organisation of the slaughtering operations, with many participating people coming from different countries. The condition coefficient $K$ was lowest in semi-intensive pond rearing in Portugal, as already reported in a previous experiment (Dupont-Nivet et al., 2008). The fish in Portugal were also the leanest (4.0\% fat in the muscle), while the fish in Canary Islands were very fatty $(10.7 \%)$, although they were the smallest at slaughter. All this reflects the differences in rearing conditions between the different sites, showing that the choice of the sites was appropriate to reveal potential GxE interactions, as it covers a wide range of rearing conditions and generates important phenotypic differences on several traits.

\subsection{Growth traits}

Body weight at tagging was studied across all sites, and was shown to be influenced by site of pre-growing (Israel or Portugal, $\mathrm{F}_{1,2790}=135.2 P<0.0001$, model 1.3), sex $\left(\mathrm{F}_{1,2775}=59.9\right.$ $P<0.0001$, higher in females, model 1.3) and nephrocalcinosis recorded at slaughter $\left(F_{1,2797}=9.22 P=0.002\right.$, model 1.3, higher in affected fish, 24.2 vs. 22.4 g) meaning that fastgrowing fish were probably more sensitive to nephrocalcinosis in the ongrowing phase. No difference between sire $\left(\mathrm{F}_{4,115}=0.83, P=0.51\right.$, model 1.3) or dam $\left(\mathrm{F}_{1,99.1}=0.15, P=0.70\right.$, model 1.3) population was seen, as well as no heterosis $\left(\mathrm{F}_{4,150}=0.63, P=0.64\right.$, model 1.1 , - see Table 2)

Body weight at slaughter showed no heterosis $\left(\mathrm{F}_{4,158}=1.89, P=0.11\right.$, model 1.1) nor $\mathrm{GxE}$ $\left(F_{12,261}=1.26, P=0.24\right.$ for sire population by site interaction, $F_{3,84.1}=0.39, P=0.76$ for dam population by site interaction, model 1.2) at the strain level. Not surprising for this species, it was strongly influenced by gender $\left(\mathrm{F}_{1,281}=155, P<0.0001\right.$, higher in females, model 1.3). Significant population effects appeared both for sire population $\left(\mathrm{F}_{4,65.7}=4.38, P=0.003\right.$, model 1.3) and dam population $\left(\mathrm{F}_{1,23.3}=7.17, P=0.013\right.$, model 1.3). The heaviest fish were NEM and SAT, while the smallest were WEM, NAT and SEM being in between (Table 2). The 
difference between the best and the worst sire lines was $12.6 \%$ of the mean, which represents a $25.2 \%$ difference in full scale (considering that comparing only sire strains means comparing only half of the genetic differences between lines). Similarly, it was found in the whole final biometry dataset (6024 fish) without gender effect included (as gender could not be recorded for the fish that were left alive), showing that the results were quite robust (data not shown). Concerning the absence of heterosis, we also tested the hypothesis of a global heterosis between Mediterranean and Atlantic origins, and it was notsignificant $(P>0.05$, data not shown).

The analysis of TGC, which demonstrated the growth of the different strains from tagging to final biometry in all sites, gave a picture quite close to that of final body weight, as there was still no heterosis between sire and dam strains $\left(\mathrm{F}_{4,150}=2.20, P=0.07\right.$, model 1.1$)$, but this time, GxE was significant when Israel was included (model 1.2: $F_{12,262}=2.82, P=0.0012$ for sire population by farm interaction, $F_{3,82.6}=1.15, P=0.33$ for dam population by farm interaction Table 2), but not when it was excluded (model 1.2: $\mathrm{F}_{8,196}=0.28, P=0.97$ for sire population by site interaction, $\mathrm{F}_{2,62.8}=0.65, P=0.53$ for dam population by site interaction), showing that the relative growth rate of the different populations was the same among the Canary Islands, France and Portugal. Then, the data were analyzed separately for Israel and the other three sites. In Israel, the fastest-growing fish were from the East-Mediterranean lines (NEM and SEM), the slowest-growing ones were NAT and WEM, while the SAT fish were in-between. The difference between the fastest and slowest growing sire lines was $7.4 \%$ of the mean, which represents a $14.8 \%$ difference in full scale (Table 3 ). In the other sites, the best growers were from the SAT and NEM sire strains, the worst ones were from the WEM and SEM sire strains, while the NAT sire strain was in-between. The difference between the extremes was $4.9 \%$, representing $9.8 \%$ in full scale. It can be noted that the differences in growth rate are lower than the differences in final weight. This is usually seen, as instantaneous growth rate has an incremental effect on weight and therefore smaller increases in growth rate can yield large increases in final weight.

\subsection{Shape and fat content}

There was neither heterosis $\left(\mathrm{F}_{4,177}=0.10, P=0.98\right.$, model 1.1) nor $\mathrm{GxE}\left(\mathrm{F}_{12,288}=1.59, P=0.09\right.$, model 1.2) on condition coefficient at slaughter. Condition coefficient gave very consistent results at tagging (data not shown) and at slaughter, with NEM and NAT fish being more rotund, WEM being thinner and SAT and SEM being in between. As usually seen in sea bass however, body weight had a very strong effect on $\mathrm{K}$, heavier fish being more rotund on 
average $\left(\mathrm{F}_{1,2848}=122, P<0.0001\right.$, model $\left.1.3 \mathrm{~b}\right)$. Then, we corrected $\mathrm{K}$ by body weight in an analysis of covariance, but the results were similar (data not shown).

The mean muscle fat content was significantly different between sites $\left(\mathrm{F}_{3,2740}=1165\right.$, $P<0.0001$ ), ranging from $4.0 \%$ in Portugal to $10.2 \%$ in Canary Islands (Israel=6.2\%, France $=5.5 \%)$. No heterosis could be seen for this trait $\left(\mathrm{F}_{4,158}=0.34, P=0.85\right.$, model 1.1), as well as no $\mathrm{GxE}$ interaction (model 1.2: $\mathrm{F}_{12,257}=1.63, P=0.08$ for sire population by site interaction, $F_{3,86.3}=1.96, P=0.13$ for dam population by site interaction ). However, body weight is known to have a very strong influence on muscle fat content, and we have tried to correct fat values by $\ln$ (slaughter weight). This could not be done across sites, as the regression slopes of fat on $\log$ (weight) were different between sites $\left(\mathrm{F}_{3,2802}=21.05, P<0.0001\right.$, model 1.1a). Then, the correction could only be done within site. However, after examining the strain values for muscle fat within each site, after correction for weight, we found out that the general picture was very similar among sites, and was also similar to the uncorrected mean of all sites. Therefore, we present only this last analysis (corresponding to model 1.3) in Table 2.

It shows that the fattest strain is NAT, closely followed by SEM. The leanest strain is WEM, and SAT and NEM are in between. The difference between the offspring of the fattest and the leanest sire line is $24.6 \%$ of the mean fat value, corresponding to $49.2 \%$ in full scale (if both sire and dams from each line were used to produce progeny groups).

\subsection{Body compartment yields}

Carcass yield was quite different between sites, $84.3 \%$ in Israel, 85.6\% in France, $86.8 \%$ in Portugal and $87.6 \%$ in Canary Islands $\left(\mathrm{F}_{3,2819}=288, P<0.0001\right)$. No heterosis could be demonstrated for this trait $\left(\mathrm{F}_{4,178}=0.46, P=0.77\right.$, model $\left.1.1 \mathrm{~b}\right)$ in the allometric regression analysis on studentized data. GxE interaction was significant (model 1.2b: $F_{12,257}=2.02$, $P=0.02$ for sire population by site interaction, $\mathrm{F}_{3,85.1}=2.33, P=0.08$ for dam population by site interaction) and the ranking of sire populations varied a lot between sites (Figure 2), however without clear pattern. When analyzed within site, the only significant differences were a better yield for WEM as compared to NAT in Israel (model 1.4b, $P<0.001$ ), and a better yield of SEM as compared to NAT in Canary Islands (model $1.4 \mathrm{~b}, P<0.05$ ).

Head yield (data not shown in Table 2) was $16.8 \%$ in Israel, $18.4 \%$ in France, $18.6 \%$ in Canary Islands and $21.2 \%$ in Portugal, a large between-site variation $\left(\mathrm{F}_{3,2829}=1309\right.$, $P<0.0001)$. In the allometric regression analysis on studentized data, no heterosis $\left(\mathrm{F}_{4,163}=0.39\right.$, 
$P=0.82$, model 1.1b) nor GxE interactions (model 1.2b: $F_{12,262}=1.77, P=0.054$ for sire population by site interaction, $\mathrm{F}_{3,78.3}=2.54, P=0.062$ for dam population by site interaction). A general sire line effect appeared $\left(\mathrm{F}_{4,72.3}=2.50, P=0.049\right.$, model $\left.1.3 \mathrm{~b}\right)$, showing that NEM had a smaller head than NAT and SAT, WEM and SEM being in between, but no dam line effect $\left(\mathrm{F}_{1,21.3}=0.61, P=0.44\right.$, model 1.3b). Females had a larger head than males $(+4.5 \%)$.

Fillet yield (calculated as twice the weight of the left fillet/live weight) showed a large between-site variation: 52.9\% in Portugal, 55.3\% in France and Israel, and 58.2\% in Canary Islands $\left(\mathrm{F}_{3,2840}=1492, P<0.0001\right)$. This was not likely to be due to an operator effect, as the same experienced person filleted all fish in all sites. In the allometric regression analysis on studentized data, no heterosis $\left(\mathrm{F}_{4,131}=0.52, P=0.72\right.$, model 1.1b), GxE interaction (model 1.2b: $\mathrm{F}_{12,256}=0.44, P=0.95$ for sire population by site interaction, $\mathrm{F}_{3,71.8}=0.24, P=0.87$ for dam population by site interaction) or population effects (model 1.3b: $\mathrm{F}_{4,69.3}=1.89, P=0.12$ for sire populations, $\mathrm{F}_{1,21.7}=0.13, P=0.72$ for dam populations) were significant (Table 2 ).

\subsection{Heritability and correlations}

The within population heritability of the different traits is presented in Table 3 . These estimates are valid under the hypothesis that there is neither heterosis nor GxE, which is the case for all traits except TGC and carcass yield where GxE is present. For TGC we studied separately TGC in Israel and in the other 3 sites, as these differences are the cause of GxE. We did not do it for carcass yield for which the picture was much more confusing. All heritabilities were in a 0.30-0.50 range, except the heritability of fillet yield, which was $0.28 \pm 0.04$.

We compared the expected genetic gain of one generation of within population individual selection at a selection pressure of $5 \%$ with the maximum difference estimated between two extreme sire populations (the maximal difference between sire population least square means was multiplied by two to estimate the full-scale additive effect of the populations). We could observe that in many cases the expected genetic gain was close to the maximum difference between strains or higher, except for TGC in Israel for which the difference between strains was 1.9 times the expected genetic gain.

The within population genetic variation of TGC in the different sites (considered as different traits in each site), and the genetic correlations of TGCs in the different sites considered as different traits are presented in Table 4 . The heritability values are in the same range as those in Table 3 (0.39 to 0.52 ), but the genetic correlations are always well below unity ( 0.38 to 0.67), showing that GXE at the family within population level is present between all sites. 


\section{Discussion}

This experiment is the first large-scale comparison of wild base population performances in sea bass, as well as the first to report the use of molecular pedigrees for a population comparison experiment. A previous paper (Gorshkov et al., 2004) reported three different sea bass population comparison experiments, using mass spawning with moderate number of broodstock fish (4-14 dams and 5-18 sires per cross). It involved a "French" population (presumably WEM kept without selection for up to six generations of captive breeding) and "Lake" and "Marine" SEM fish (which are the parents of the SEM broodstock fish used in the present study - for which we have no remaining indication of the lake or marine origin). No heterosis was seen in Gorshkov et al. (2004), and some differences between populations and their crosses were observed, but were mostly not repeatable between experiments, except for a higher K, a higher proportion of females and a higher percentage of deformities in the French population and its crosses (Gorshkov et al., 2004). Two methodological points can to some extent explain this low repeatability: first, it is well known that in sea bass mass spawnings, the number of fish producing progeny can be much lower than the number of broodstock present (see Chatziplis et al., 2007), thus potentially leading to genetic sampling effects that may bias the mean performance of the crosses tested. Second, the experiment by Gorshkov et al. was done with initial separate rearing of the different crosses, without replicates until tagging at fish weight of $40 \mathrm{~g}$ and communal rearing thereafter. Thus, even with excellent zootechny it is very likely that initial common environment effects may also have influenced the mean performance of each cross. In the present experiment, these potential problems were solved by using 1) artificial fertilization to produce controlled numbers of fish from each broodstock used and 2) communal rearing from incubation to slaughter, with a posteriori identification of progenies and populations by genotyping of microsatellite markers. We may therefore be more confident in the reliability of the results produced.

\subsection{Mean performances of the populations tested}

A general feature of the results obtained here is that we could find additive population effects on almost all performances studied, except tagging weight and fillet yield. No heterosis appeared for any of the production and processing traits studied here (although it was not very far from significance for TGC outside Israel, $P=0.06$ and muscle fat content, $P=0.08$ ), confirming the observations of Gorshkov et al. (2004). However, it must be noted that heterosis effects were revealed for survival and sex-ratio in our experiment (Guinand et al., 
submitted). Heterosis in fish strains comparison, although frequently reported in carp (e.g. Wohlfarth, 1993; Bialowas et al., 1997) is generally low in other species like salmon (Gjerde and Refstie, 1984) or tilapia (Bentsen et al., 1998), and even when present appears to be very unstable in brook trout (Crespel et al., 2012).

The size of the population effects on the performances studied was moderately high for growth traits (10 to $25 \%$ of the mean - Table 3), low for conformation and processing traits (3.0 to $6.2 \%$ of the mean), and highest for muscle fat content ( $49 \%$ of the mean). It must be noted that at least for growth, the differences in population means observed in communal rearing may be larger than the real population differences, being amplified by competition effects. This is well demonstrated for growth in common carp (Moav and Wohlfarth, 1974) and in sea bass (Vandeputte et al., 2009), but to our knowledge such amplification effects have never been demonstrated on other traits. Taking into account the fact that population differences on body weight can be approximately twice as high in communal rearing compared to separate rearing (Vandeputte et al., 2009), it is possible that the real difference between the populations tested is only $13 \%$ of the mean weight instead of $25 \%$.

It has often been proposed that appropriate strain comparison is the best way to start a breeding programme in fish, as a good choice could spare several generations of within-strain selection (e.g Ponzoni et al., 2013). It is indeed true that high between strain differences have been found in e.g. insalmonids (Gunnes and Gjedrem, 1978; Morkramer et al., 1985; Kincaid, 1994) or in carp (see review in Vandeputte, 2003).In sea bass, the differences were quite significant for several traits, but with the exception of TGC in Israel, they are all of the same magnitude as the genetic gain predicted for one generation of individual selection (Table 2). This makes the choice of the initial strain an important point but not an essential one in this species.

Moreover, it can be remarked that the "ideal" strain does not exist, as favourable characteristics (high growth, low fat, long shape, high processing yields) are distributed among different lines (Table 2), which do not provide an easy general strategy. One point that we can note is that the WEM line had a very poor growth in most sites. Its high carcass yield 
(linked to low viscera weight and hence low perivisceral fat) and low muscle fat could be a consequence of low growth and poor feed intake rather than specific qualities.

\subsection{Genotype by environment interactions}

Genotype by environment interaction was present at the population level only for TGC and for carcass yield. For TGC, it appeared that the populations had different rankings in Israel, while their performance was consistent across the other three sites. The Israel site is specific in two respects, first because the rearing temperature is much higher than in the other sites (Table 1$)$, and can reach very high peak values $\left(28^{\circ} \mathrm{C}\right)$, but also because fish were sent there earlier than in the other sites (at 1.6g instead 27-29 g). Then, the higher GxE interaction could originate in the specific rearing conditions, in the longer duration of the separate phase, in a difference of age at slaughter (in this case a genotype by age interaction) or in a combination of those. It is worth noting that SEM fish were very bad growers in all sites except Israel, where they were the best growers. It could be a specific adaptation to high temperature of fish from the South East Mediterranean, which is the warmest area of collection of our broodstocks. Such latitudinal adaptation has already been seen (although with low betweenyears repeatability) in the striped bass (Conover et al., 1997), but was completely absent in the Norwegian salmon strain-testing programme (Gunnes and Gjedrem, 1978). In our case, the fact that neither population differences nor GxE interactions appeared at tagging although one batch of fish had already been reared in Israel from 1.6 to $20 \mathrm{~g}$ does not strongly support this temperature adaptation hypothesis. Another concurrent explanation would be linked to the fact that our SEM broodstock were not wild, but issued from the first generation of captive breeding of wild SEM fish. This generation of captive breeding was done in Israel, in conditions similar to the ones they experienced in our grow-out experiment. Fast domestication selection for adaptation to high temperature cannot be excluded, as domestication selection is suspected to happen rapidly in marine fish (Doyle et al., 1995, but see Vandeputte et al., 2009 in sea bass).

When studying genotype by environment interactions at the family within population level, we found low genetic correlations for TGC between sites ( 0.38 to 0.67$)$, confirming previous results on multisite-testing of the NAT population of sea bass, where between-sites correlations ranged between 0.21 and 0.78 for growth rate (Dupont-Nivet et al., 2010). Contrary to GxE at the population level which appears to be low between Canary Islands, France and Portugal for TGC (NS, P>0.50), genetic correlations at the family level are 
indicative of significant interactions among these three sites, as genetic correlations range from $0.55 \pm 0.09$ to $0.67 \pm 0.07$, which clearly differ from unity. Then although different natural populations may have quite stable growth performances across sites (except in high temperature conditions), it can be foreseen that growth selected fish may not express all their potential in many different situations, as no genetic correlation for TGC estimated here exceeded 0.67 . These genotype by site interactions could also be interpreted at least partly as genotype by age interactions, as the ages at slaughter differed quite significantly among sites (from 377dpf in Israel to 551dpfs in Portugal). However, within environment genetic correlations between body weights at different ages in sea bass have been shown to be high $\left(\mathrm{r}_{\mathrm{A}}>0.9\right.$ for any age difference below 152 days, $>0.8$ for 152 days, Le Boucher et al., 2013), so that it seems reasonable that most of the interactions seen between sites are indeed GxE. In the past, genotype by environment interaction for growth was seen as a low-impact question in fish breeding, which could be neglected in most cases (see e.g. Gjedrem, 2005). However, more and more recent results show high levels of GxE at the family level (Dupont-Nivet et al., 2010; Sae-Lim et al., 2012; Mas-Munoz et al., 2013). As global fish breeding programs are being developed, this question may become more and more important.

The second trait for which GxE interaction appeared in this experiment was carcass yield (Table 2, Figure 2). We hypothesized before that the high carcass yield (and muscle fat content) of the WEM population observed quite consistently might be a consequence of its low growth rate. However, in Israel, WEM was the worst population for growth and the highest for carcass yield, while NAT is the second worst grower but has the worst carcass yield. This shows that there is no systematic link between poor growth and high carcass yield. We had already seen in a previous experiment (unpublished data) that the perivisceral fat content of Atlantic fish reared in Israel was very high, so this observation seems repeatable (although we had no other strain to compare with in the previous experiment). Estimates of genotype by environment interactions for processing traits are scarce in the literature and have been shown to be low in cattle (Ibi et al., 2005) and pig (Brandt et al., 2010). In fish, they have been mostly studied in the case of alternative diets, for which lipid deposition shows moderate GxE interaction ( $r=0.69$ ) in whitefish (Kause et al., 2009), fillet yield shows no GxE interaction $\left(r_{A}>0.9\right)$ between normal and high protein diets in rainbow trout (Tobin et al., 2006), and carcass yield shows no interaction $\left(r_{A}=0.90 \pm 0.06\right)$ between plant-based and marine diets in rainbow trout (Le Boucher et al., 2011). However, due to the poikilothermic status of fish and to the high variation in temperature seen between rearing sites, GxE interactions may 
be a concern for the future. Here, the maladaptation of the NAT strain to Israeli conditions (in terms of carcass yield and also growth) seems rather clear, while it has acceptable performance in other places.

\section{Conclusion}

This experiment is the first large-scale comparison of sea bass base populations for aquaculture, and is also the first large scale experiment using molecular pedigree tracing to perform strain comparison in common garden and multi-site conditions.

As for growth and processing traits, we have shown that there is a significant genetic variation between populations, with no heterosis and little GxE interactions, except for growth rate and carcass yield that can be important. GxE interactions mostly occur between the warmest site and the other three when studied at the population level. However, they appear to be present between all sites for growth rate studied at the family within population level.

No "perfect" strain could be identified, and thus sea bass breeders will have to choose the appropriate base population while taking into account their prioritary breeding goals. Interestingly enough, for most traits, one generation of intense mass selection would be enough to catch up the difference that would be created from an inappropriate population choice for a given trait.

\section{Acknowledgements}

This work is part the COMPETUS project, funded by Ardag Red Sea Mariculture (Eilat, Israel), Ecloserie Marine de Gravelines (Gravelines, France), Les Poissons du Soleil (Balaruc, France), Tinamenor SA (Pesues, Cantabria, Spain), Viveiro Vilanova (Vila Nova de Milfontes, Portugal) and the European Union (project COOP-CT-2005-017633). It is also part of the programme of the Research Group "Fish Genetic Improvement" between INRA and 
Ifremer. We wish to thank Haydar Fersoy and Sergei Ghorshkov for giving access to the gametes of some of the wild populations used. 


\section{Figure Captions}

Figure 1: Flow chart of the fish used in the experiment. $\mathrm{T}=$ tagging date, $\mathrm{S}=$ slaughter date

Figure 2: Residual of the regression of studentized $\ln$ (carcass weight) on studentized $\ln$ (body weight) for the offspring of 5 sire populations of sea bass reared in four different sites. Significant differences within site: $* P<0.05 * * * P<0.001$ 


\section{Tables}

Table : Summary of the experimental data and mean performance of the sea bass in all rearing sites. $\mathrm{N}$ good data: number of uniquely assigned fish with coherent data for all traits. CV\%: coefficient of variation (standard deviation /mean) of the trait

\begin{tabular}{lcccc}
\hline & Israel & Canary Islands & France & Portugal \\
\cline { 2 - 5 } Age at slaughter $(\mathbf{d p f})$ & 377 & 446 & 524 & 551 \\
Mean rearing $\mathbf{T}^{\circ} \mathbf{C}$ & $24.4^{\circ} \mathrm{C}$ & $20.6^{\circ} \mathrm{C}$ & $19.4^{\circ} \mathrm{C}$ & $18.2^{\circ} \mathrm{C}$ \\
Final rearing density $\left(\mathbf{k g} / \mathbf{m}^{\mathbf{3}}\right)$ & 6.7 & 15.3 & 16.6 & 0.52 \\
N at slaughter & 1621 & 1592 & 1666 & 1573 \\
N slaughtered $(\mathbf{N}$ good data) & $737(719)$ & $775(754)$ & $749(732)$ & $742(683)$ \\
N kept alive $(\mathbf{N}$ good data) & $708(702)$ & $811(803)$ & $917(884)$ & $831(755)$ \\
Slaughter weight g $(\mathbf{C V \%})$ & $248(26 \%)$ & $144(29 \%)$ & $199(31 \%)$ & $151(24 \%)$ \\
Slaughter length $\mathbf{~ m m ~}(\mathbf{C V} \%)$ & $226(8 \%)$ & $189(9 \%)$ & $211(10 \%)$ & $197(8 \%)$ \\
K $(\mathbf{C V} \%)$ & $2.09(8 \%)$ & $2.07(7.4 \%)$ & $2.05(7.8 \%)$ & $1.92(6.9 \%)$ \\
Mean muscle fat \% $(\mathbf{C V \% )}$ & $6.4(26 \%)$ & $10.7(32 \%)$ & $5.9(48 \%)$ & $4.0(37 \%)$ \\
DGC*100 $(\mathbf{C V \% )}$ & $0.018(10 \%)$ & $0.012(17 \%)$ & $0.010(14 \%)$ & $0.008(11 \%)$ \\
TGC*100 base 10 ${ }^{\circ} \mathbf{C}$ & 0.132 & 0.086 & 0.108 & 0.096 \\
\hline
\end{tabular}


Table2: Genetic variation at the sire and dam population level from 2888 juvenile sea bass from ten population crosses, reared in four different locations. F-tests and significance are given for GxE interactions, heterosis (sire population * dam population interaction), and sire population as well as dam population additive effects.

\begin{tabular}{|c|c|c|c|c|c|c|c|c|}
\hline Trait & $\begin{array}{l}\text { Tagging body } \\
\text { weight }^{(1)} \text { (g) }\end{array}$ & $\begin{array}{l}\text { Final body } \\
\text { weight }^{(1)}(\mathrm{g})\end{array}$ & $\begin{array}{l}\text { TGC Israel } \\
\left(\mathbf{x 1 0}^{3}\right)\end{array}$ & $\begin{array}{l}\text { TGC others } \\
\left(\mathbf{x 1 0}^{3}\right)\end{array}$ & $\begin{array}{l}\text { Condition } \\
\text { coefficient (K) }\end{array}$ & $\begin{array}{l}\text { Muscle fat } \\
\text { content }\end{array}$ & $\begin{array}{l}\text { Carcass yield } \\
\text { (2) }\end{array}$ & Fillet yield $^{(2)}$ \\
\hline $\begin{array}{l}\text { ATOL } \\
\text { ID* }\end{array}$ & ATOL:0000351 & ATOL:0000351 & ATOL:0001661 & ATOL:0001661 & 53 & ATOL:0001663 & ATOL:0000548 & ATOL:0000130 \\
\hline $\begin{array}{l}\text { GxE P- } \\
\text { value }^{(3)}\end{array}$ & $\begin{array}{c}\mathrm{F}_{1,47.8}=0.96 \\
P=0.33\end{array}$ & $\begin{array}{c}\mathrm{F}_{12,261}=1.26 \\
P=0.24\end{array}$ & $\begin{array}{l}\mathrm{F}_{12,262}=2.82 \\
P=0.001\end{array}$ & $\begin{array}{l}\mathrm{F}_{2,63}=0.59 \\
P=0.56^{(5)}\end{array}$ & $\begin{array}{c}\mathrm{F}_{12,288}=1.59 \\
P=0.09\end{array}$ & $\begin{array}{c}\mathrm{F}_{12,257}=1.63 \\
P=0.08\end{array}$ & $\begin{array}{c}\mathrm{F}_{12,257}=2.02 \\
P=0.02\end{array}$ & $\begin{array}{c}\mathrm{F}_{3,71.8}=0.24 \\
P=0.86\end{array}$ \\
\hline $\begin{array}{l}\text { Heterosis } \\
\text { P-value }\end{array}$ & $\begin{array}{c}\mathrm{F}_{4,150}=0.63 \\
P=0.64\end{array}$ & $\begin{array}{c}\mathrm{F}_{4,158}=1.89 \\
P=0.11\end{array}$ & $\begin{array}{c}\mathrm{F}_{4,71.6}=0.78 \\
P=0.54^{(5)}\end{array}$ & $\begin{array}{c}\mathrm{F}_{4,138}=2.31 \\
P=0.06^{(5)}\end{array}$ & $F_{4,177}=0.10$ & $\begin{array}{c}\mathrm{F}_{4,158}=0.34 \\
P=0.85\end{array}$ & $\begin{array}{c}\mathrm{F}_{4,178}=0.46 \\
P=0.77\end{array}$ & $\begin{array}{c}\mathrm{F}_{4,131}=0.52 \\
P=0.72\end{array}$ \\
\hline $\begin{array}{l}\text { Sire line } \\
P \text {-value }\end{array}$ & $\begin{array}{c}\mathrm{F}_{4,115}=0.83 \\
P=0.51\end{array}$ & $\begin{array}{c}\mathrm{F}_{4,65.7}=4.38 \\
P=0.003\end{array}$ & $\begin{array}{c}\mathrm{F}_{4,64.6}=10.36 \\
P<0.0001\end{array}$ & $\begin{array}{c}\mathrm{F}_{4,67.3}=5.39 \\
P=0.0008\end{array}$ & $\begin{array}{c}\mathrm{F}_{4,66.6}=4.59 \\
P=0.0025\end{array}$ & $\begin{array}{l}\mathrm{F}_{4,64.6}=9.50 \\
P=<0.0001\end{array}$ & $\begin{array}{l}\mathrm{F}_{4,69.3}=4.33 \\
P=0.0035^{(6)}\end{array}$ & $\begin{array}{c}\mathrm{F}_{4,69.3}=1.89 \\
P=0.12\end{array}$ \\
\hline
\end{tabular}

Sire line LS-means \pm s.e.

\begin{tabular}{|c|c|c|c|c|c|c|c|c|}
\hline NAT & $23.5 \pm 0.9^{\mathrm{a}}$ & $176.7 \pm 5.6^{\mathrm{ab}}$ & $1.28 \pm 0.02^{b}$ & $0.94 \pm 0.01^{\mathrm{ab}}$ & $2.10 \pm 0.02^{\mathrm{ab}}$ & $7.78 \pm 0.29^{\mathrm{a}}$ & $83.7 \pm 0.2 \%{ }^{b}$ & $55.3 \pm 0.4 \%^{\mathrm{a}}$ \\
\hline SAT & $23.7 \pm 0.9^{\mathrm{a}}$ & $186.3 \pm 6.1^{\mathrm{a}}$ & $1.33 \pm 0.02^{\mathrm{ab}}$ & $0.97 \pm 0.01^{\mathrm{a}}$ & $2.08 \pm 0.02^{\mathrm{ab}}$ & $6.81 \pm 0.30^{b c}$ & $84.2 \pm 0.2 \%{ }^{a b}$ & $55.5 \pm 0.4 \%^{\mathrm{a}}$ \\
\hline WEM & $22.2 \pm 0.9^{\mathrm{a}}$ & $167.3 \pm 5.6^{\mathrm{b}}$ & $1.28 \pm 0.02^{b}$ & $0.92 \pm 0.01^{b}$ & $2.04 \pm 0.02^{c}$ & $6.20 \pm 0.31^{\mathrm{c}}$ & $85.0 \pm 0.3 \%^{\mathrm{a}}$ & $55.9 \pm 0.4 \%{ }^{\mathrm{a}}$ \\
\hline NEM & $24.2 \pm 0.9^{\mathrm{a}}$ & $190.2 \pm 6.2^{\mathrm{a}}$ & $1.37 \pm 0.02^{\mathrm{a}}$ & $0.97 \pm 0.01^{\mathrm{a}}$ & $2.11 \pm 0.02^{\mathrm{a}}$ & $6.74 \pm 0.30^{\mathrm{bc}}$ & $84.3 \pm 0.2 \%{ }^{\mathrm{ab}}$ & $55.2 \pm 0.4 \%^{\mathrm{a}}$ \\
\hline SEM & $23.2 \pm 0.9^{\mathrm{a}}$ & $177.2 \pm 5.6^{\mathrm{ab}}$ & $1.38 \pm 0.02^{\mathrm{a}}$ & $0.92 \pm 0.01^{b}$ & $2.05 \pm 0.02^{\mathrm{bc}}$ & $7.41 \pm 0.29^{\mathrm{a}}$ & $84.2 \pm 0.2 \%{ }^{\mathrm{ab}}$ & $55.0 \pm 0.4 \%^{\mathrm{a}}$ \\
\hline $\begin{array}{l}\text { Dam line } \\
P \text {-value }\end{array}$ & $\begin{array}{c}\mathrm{F}_{4,99.1}=0.15 \\
P=0.70\end{array}$ & $\begin{array}{c}\mathrm{F}_{1,23.3}=7.17 \\
P=0.013\end{array}$ & $\begin{array}{c}\mathrm{F}_{1,18.8}=4.82 \\
P=0.04\end{array}$ & $\begin{array}{c}\mathrm{F}_{1,22.9}=21.8 \\
P=0.0001\end{array}$ & $\begin{array}{c}\mathrm{F}_{1,23.1}=11.1 \\
P=0.0029\end{array}$ & $\begin{array}{c}\mathrm{F}_{1,22.7}=7.35 \\
P=0.013\end{array}$ & $\begin{array}{c}\mathrm{F}_{1,21.4}=2.59 \\
P=0.12^{(6)}\end{array}$ & $\begin{array}{c}\mathrm{F}_{1,21.7}=0.13 \\
P=0.72\end{array}$ \\
\hline \multicolumn{6}{|c|}{ Dam line LS-Means \pm s.e. } & \multicolumn{3}{|c|}{ (6) } \\
\hline NAT & $23.2 \pm 0.9^{\mathrm{a}}$ & $188.5 \pm 6.4^{\mathrm{a}}$ & $1.35 \pm 0.02^{\mathrm{a}}$ & $0.98 \pm 0.01^{\mathrm{a}}$ & $2.12 \pm 0.02^{\mathrm{a}}$ & $7.55 \pm 0.36^{\mathrm{a}}$ & $84.3 \pm 0.2 \%{ }^{\mathrm{a}}$ & $55.6 \pm 0.4 \%^{\mathrm{a}}$ \\
\hline WEM & $23.5 \pm 0.8^{\mathrm{a}}$ & $170.9 \pm 4.7^{\mathrm{b}}$ & $1.31 \pm 0.01^{\mathrm{b}}$ & $0.91 \pm 0.01^{\mathrm{b}}$ & $2.04 \pm 0.02^{\mathrm{b}}$ & $6.42 \pm 0.28^{\mathrm{b}}$ & $84.3 \pm 0.2 \%^{\mathrm{a}}$ & $55.2 \pm 0.4 \%^{\mathrm{a}}$ \\
\hline
\end{tabular}

* trait identifier according to Animal Trait Ontology for Livestock http://www.atol-ontology.com/index.php/en/les-ontologies-en/visualisation-en

${ }^{(1)}$ studied as $\ln$ (Body weight) and back-transformed to original scale ${ }^{(2)}$ studied as the residual of $\ln$ (compartment weight) regressed on $\ln ($ body weight) and back-transformed to original scale ${ }^{(3)}$ minimum of the $P$-value of site *sire population and site*dam population $P$-value ${ }^{(4)} P$-value for the global model with all sites ${ }^{(5)} P$-value for the site-specific model ${ }^{(6)}$ Values given for Israel only due to GxE interactions. see text and figure 1 for more details 
Table 3: Within-population heritability for the traits studied, and comparison between the expected genetic gain for one generation of mass selection with 5\% selection pressure and the maximum difference between the five sire strains compared. Phenotypic SD is calculated as the residual standard deviation within fixed effects divided by the overall mean of the trait. Genetic gain $\Delta \mathrm{G}$ calculated from the breeder's equation (Falconer and Mackay, 1996). Maximum strain difference is calculated as twice the difference between extreme sire populations least square means

\begin{tabular}{|c|c|c|c|c|c|c|}
\hline Trait & ATOL ID* & $h^{2} \pm$ s.e. & mean & $\begin{array}{c}\text { Phenotypic } \\
\text { SD }\end{array}$ & $\begin{array}{l}\Delta \mathrm{G} \text { for } \\
\mathrm{p}=5 \%\end{array}$ & $\begin{array}{c}\text { Maximum strain } \\
\text { difference ( } \% \text { of } \\
\text { mean) }\end{array}$ \\
\hline $\begin{array}{l}\text { tagging } \\
\text { BW }^{(1)}\end{array}$ & ATOL:0000351 & $0.34 \pm 0.04$ & $23.4 \mathrm{~g}$ & & $4.8 \mathrm{~g}$ & $3.9 \mathrm{~g}(16.7 \%)$ \\
\hline final $B W^{a}$ & ATOL:0000351 & $0.38 \pm 0.04$ & 179. & $53.6 \mathrm{~g}$ & $42.1 \mathrm{~g}$ & $45.2 \mathrm{~g}(25.2 \%)$ \\
\hline $\begin{array}{l}\text { TGC } \\
\text { Israel } \\
\left(\mathbf{x 1 0}^{3}\right)\end{array}$ & ATOL:0001661 & $0.41 \pm 0.06$ & .33 & 0.119 & 0.106 & $0.197(14.8 \%)$ \\
\hline $\begin{array}{c}\text { TGC } \\
\text { others } \\
(\mathbf{x 1 0})\end{array}$ & ATOL:0001661 & $0.43 \pm 0.05$ & 0.943 & 0.148 & 0.126 & $0.093(9.8 \%)$ \\
\hline Final $\mathrm{K}$ & ATOL:000165 & $0.49 \pm 0.05$ & 2.08 & 0.141 & 0.143 & $0.129(6.2 \%)$ \\
\hline $\begin{array}{l}\text { Carcass } \\
\text { yield }^{b}\end{array}$ & ATOL:0000548 & $0.48 \pm 0.06$ & $86.1 \%$ & $2.5 \%$ & $2.0 \%$ & $2.6 \%(3.0 \%)$ \\
\hline$\underset{b}{\text { Fillet yield }}$ & ATOL:0000130 & $0.28 \pm 0.04$ & $55.4 \%$ & $3.6 \%$ & $2.1 \%$ & $1.8 \%(3.2 \%)$ \\
\hline Muscle fat & ATOL:0001663 & $0.47 \pm 0.05$ & $6.5 \%$ & $2.8 \%$ & $2.8 \%$ & $3.2 \%(49.2 \%)$ \\
\hline
\end{tabular}

* trait identifier according to Animal Trait Ontology for Livestock http://www.atolontology.com/index.php/en/les-ontologies-en/visualisation-en

${ }^{a}$ studied as $\ln (\mathrm{BW})$ and back-transformed to original scale

${ }^{\mathrm{b}}$ studied as residual of the $\log$-log regression on $\ln (\mathrm{BW})$ and back-transformed to original scale 
Table 4: Heritability ( \pm s.e., in bold on the diagonal) and genetic correlations ( \pm s.e.) of Thermal Growth Coefficient (TGC) of sea bass from tagging at $20 \mathrm{~g}$ to slaughter at $200 \mathrm{~g}$ in four different rearing sites.

\begin{tabular}{|c|c|c|c|c|}
\hline & \multicolumn{3}{|c|}{ Canary } & \\
\hline & Israel & Islands & France & Portugal \\
\hline Israel & $0.41 \pm 0.06$ & $0.60 \pm 0.08$ & $0.44 \pm 0.10$ & $0.38 \pm 0.11$ \\
\hline Canary Islands & & $0.52 \pm 0.06$ & $0.67 \pm 0.07$ & $0.55 \pm 0.09$ \\
\hline France & & & $0.39 \pm 0.04$ & $0.63 \pm 0.09$ \\
\hline Portugal & & & & $0.39 \pm 0.05$ \\
\hline
\end{tabular}




\section{Figures}

Figure 1

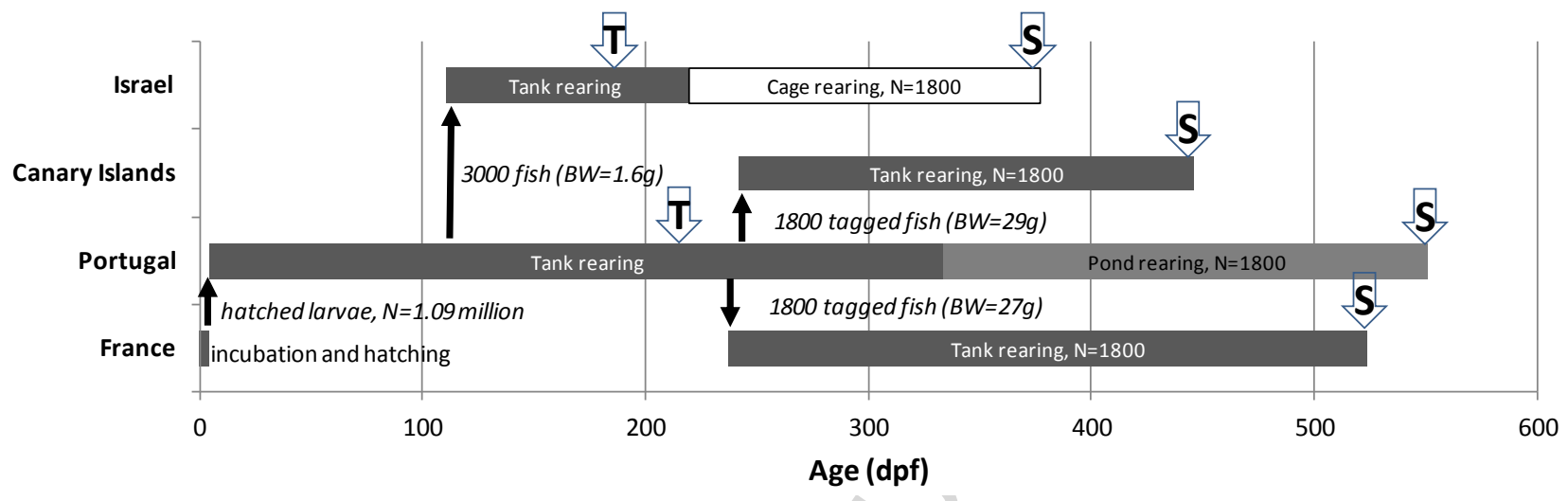

Figure 2

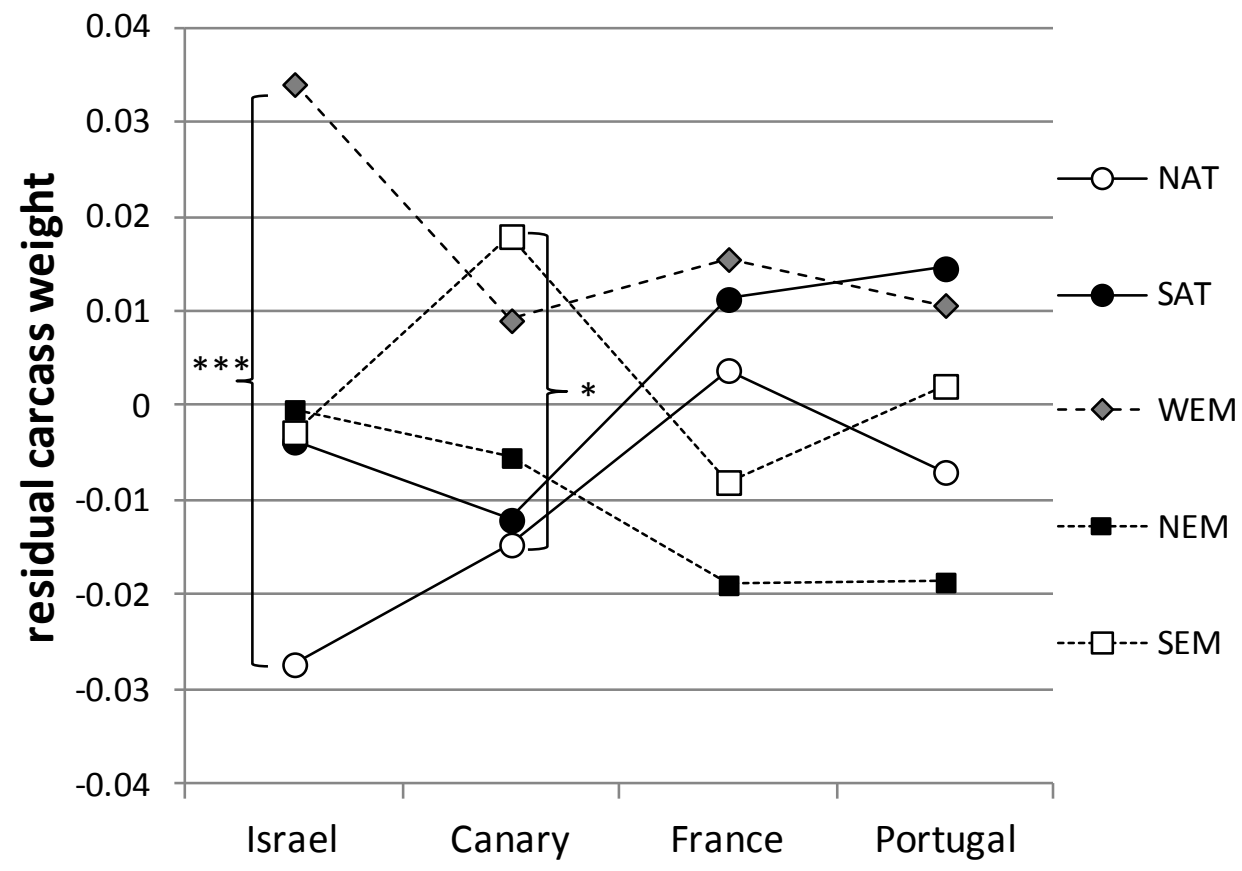




\section{References}

Bahri-Sfar, L., Lemaire, C., Ben Hassine, O.K., Bonhomme, F., 2000. Fragmentation of sea bass populations in the Western and Eastern Mediterranean as revealed by microsatellite polymorphism. Proc. R. Soc. B 267, 929-935.

Bentsen, H.B., Eknath, A.E., Palada-de-Vera, M.S., Danting, J.C., Bolivar, H.L., Reyes, R.A., Dionisio, E.E., Longalong, F.M., Circa, A.V., Tayamen, M.M., Gjerde, B., 1998. Genetic improvement of farmed tilapias: growth performance in a complete diallel cross experiment with eight strains of Oreochromis niloticus. Aquaculture 160, 145-173.

Bialowas, H., Irnazarow, I., Pruszynski, T., Gaj, C., 1997. The effect of heterosis in inter-line crossing of common carp. Arch. Ryb. Pol. 5, 13-20.

Brandt, H., Werner, D.N., Baulain, U., Brade, W., Weissmann, F., 2010. Genotype x environment interactions for growth and carcass traits in different pig breeds kept under conventional and organic production systems. Animal 4, 535-544.

Castilho, R., Ciftci, Y., 2005. Genetic differentiation between close eastern Mediterranean Dicentrarchus labrax (L.) populations. J. Fish Biol. 67, 1746-1752.

Chatziplis, D., Batargias, C., Tsigenopoulos, C.S., Magoulas, A., Kollias, S., Kotoulas, G., Volckaert, F.A.M., Haley, C.S., 2007. Mapping quantitative trait loci in European sea bass (Dicentrarchus labrax): The BASSMAP pilot study. Aquaculture 272, S172-S182.

Chistiakov, D.A., Hellemans, B., Tsigenopoulos, C.S., Law, A.S., Bartley, N., Bertotto, D., Libertini, A., Kotoulas, G., Haley, C.S., Volckaert, F.A.M., 2004. Development and linkage relationships for new microsatellite markers of the sea bass (Dicentrarchus labrax L.). Anim. Genet. $35,53-57$.

Ciftci, Y., Castilho, R., McAndrew, B.J., 2002. More polymorphic microsatellite markers in the European sea bass (Dicentrarchus labrax L.). Mol. Ecol. Notes 2, 575-576.

Conover, D.O., Brown, J.J., Entisham, A., 1997. Countergradient variation in growth of young striped bass (Morone saxatilis) from different latitudes. Can. J. Fish. Aquat. Sci. 54, 2401-2409.

Crespel, A., Audet, C., Bernatchez, L., Garant, D., 2012. Effects of Rearing Environment and Strain Combination on Heterosis in Brook Trout. North American Journal of Aquaculture 74, 188-198.

Doyle, R.W., Herbinger, C.M., Taggart, C.T., Lochmann, S., 1995. Use of DNA microsatellite polymorphism to analyse genetic correlations between hatchery and natural fitness. Am. Fish. Soc. Symp. 15, 205-211. 
Dupont-Nivet, M., Vandeputte, M., Vergnet, A., Merdy, O., Haffray, P., Chavanne, H., Chatain, B., 2008. Heritabilities and GxE interactions for growth in the European sea bass (Dicentrarchus labrax L.) using a marker-based pedigree. Aquaculture, 81-87.

Dupont-Nivet, M., Karahan-Nomm, B., Vergnet, A., Merdy, O., Haffray, P., Chavanne, H., Chatain, B., Vandeputte, M., 2010. Genotype by environment interactions for growth in European seabass (Dicentrarchus labrax) are large when growth rate rather than weight is considered. Aquaculture 306, 365-368.

Falconer,D.S., Mackay, T.F.C., 1996. Introduction to quantitative genetics. Longman, Harlow, England, $455 \mathrm{pp}$.

Fauvel, C., Suquet, M., Dréanno, C., Zonno, V., Menu, B., 1998. Cryopreservation of sea bass (Dicentrarchus labrax) spermatozoa in experimental and production simulating conditions. Aquat. Living Resour. 11, 387-394.

Garcia De Leon, F.J., Dallas, J.F., Chatain, B., Canonne, M., Versini, J.J., Bonhomme, F., 1995. Development and use of microsatellite markers in sea bass, Dicentrarchus labrax (Linneaus, 1758) (Perciformes: Serranidae). Mol. Mar. Biol. Biotech. 4, 62-68.

Gjedrem T.,2005. Genotype - environment interaction. In: Gjedrem T. (Ed.), Selection and breeding programs in aquaculture. Springer, Dordrecht, The Netherlands, pp. 233-242.

Gjedrem, T., 2010. The first family-based breeding program in aquaculture. Rev. Aquaculture 2, 215.

Gjedrem, T., Robinson, N., Rye, M., 2012. The importance of selective breeding in aquaculture to meet future demands for animal protein: A review. Aquaculture 350-353, 117-129.

Gjerde, B., Refstie, T., 1984. Complete diallel cross between five strains of Atlantic salmon. Livest. Prod. Sci. 11, 207-226.

Golik, W., Dameron, O., Bugeon, J., Fatet, A., Hue, I., Hurtaud, C., Reichstadt, M., MeunierSalaün, M.C., Vernet, J., Joret, L., Papazian, F., Nédellec, C., Le Bail, P.Y., 2012. ATOL: the multispecies livestock trait ontology. 6th International Conference on Metadata and Semantic Research, 28-30 Nov.2012, Cadiz, Spain.

Gorshkov, S., Gorshkova, G., Meiri, I., Gordin, H., 2004. Culture performance of different strains and crosses of the European sea bass (Dicentrarchus labrax) reared under controlled conditions at Eilat, Israel. J. Appl. Ichthyol. 20, 194-203.

Groeneveld,E., Kovac, M., Mielenz, N., 2008. VCE user's guide and reference manual version 6.0. Friedrich Loeffler Institute, Neustadt, Germany, 125 pp. 
Gunnes, K., Gjedrem, T., 1978. Selection experiments with salmon. IV. Growth of Atlantic salmon during two years in the sea. Aquaculture 15, 19-33.

Haffray, P., Labbé, C., IMV Technologies, Maisse, G., 2008. Fish sperm cryopreservation in France: from laboratory studies to application in selective breeding programs. Cybium 32, 127-129.

Ibi, T., Hirooka, H., Kahi, A.K., Sasae, Y., Sasaki, Y., 2005. Genotype x environment interaction effects on carcass traits in Japanese Black cattle. J. Anim. Sci. 83, 1503-1510.

Kause, A., Quinton, C.D., Ruohonen, K., Koskela, J., 2009 Genetic potential for the regulation of variability in body lipid and protein content of European whitefish. Brit. J. Nutr. 101, 1444-1451.

Kerby, J.H., 1983. Cryogenic preservation of sperm from striped bass. Trans. Am. Fish. Soc. 112, 86-94.

Kincaid, H.L., 1994. Hatchery Performance of Six Atlantic Salmon Stocks from Fry to Smolt. The Progressive Fish-Culturist 56, 111-116.

Le Boucher, R., Quillet, E., Vandeputte, M., Lecalvez, J.M., Goardon, L., Chatain, B., Médale, F., Dupont-Nivet, M., 2011. Plant-based diet in rainbow trout (Oncorhynchus. mykiss): are there genotype-diet interactions for main production traits when fish are fed marine vs plant-based diets from the first meal? Aquaculture 321, 41-48.

Le Boucher, R., Vandeputte, M., Dupont-Nivet, M., Quillet, E., Ruelle, F., Vergnet, A., Kaushik, S., Médale, F., Chatain, B., 2013. Genotype by diet interactions in European sea bass (Dicentrarchus labrax, L.) in case of a nutritional challenge on totally plant-based diets. J. Anim. Sci. 91, 44-56. Littell,R.C., Freund, R.J., Spector, P.C., 1991. SAS System for linear models. SAS Institute Inc., Cary, NC, 329 pp.

Marcil, J., Swain, D.P., Hutchings, J.A., 2006. Countergradient variation in body shape between two populations of Atlantic cod (Gadus morhua). Proc. R. Soc. B 273, 217-223.

Mas-Munoz, J., Blonk, R., Schrama, J.W., van Arendonk, J., Komen, H., 2013. Genotype by environment interaction for growth of sole (Solea solea) reared in an intensive aquaculture system and in a semi-natural environment. Aquaculture.

Moav, R., Wohlfarth, G.W., 1974. Magnification through competition of genetic differences in yield capacity in carp. Heredity 33, 181-202.

Morkramer, S., Hörstgen-Schwark, G., Langholz, H.J., 1985. Comparison of different European rainbow trout populations under intensive production conditions. Aquaculture 44, 303-320.

Naciri, M., Lemaire, C., Borsa, P., Bonhomme, F., 1999. Genetic study of the 
Atlantic/Mediterranean transition in sea bass (Dicentrarchus labrax). J. Hered. 90, 591-596.

Ponzoni RW, James JW, Nguyen NH, Mekkawy W, Khaw HL, 2013. Strain comparisons in aquaculture species: a manual. Manual, -31 .

Sae-Lim, P., Mulder, H.A., Komen, H., Kause, A., Arendonk, J.v., Martin, K., Parsons, J.E., 2012. Genotype-by-environment interaction for growth traits in rainbow trout: a continental scale study. International symposium on genetics in aquaculture XI, Auburn University, Alabama, USA, June 25-29, 2012: abstract book.

Sansone, G., Fabbrocini, A., Ieropoli, S., Langellotti, A.L., Occidente, M., Matassino, D., 2002.

Effects of extender composition, cooling rate, and freezing on the motility of sea bass

(Dicentrarchus labrax, L.) spermatozoa after thawing. Cryobiology 44, 229-239.

Teletchea, F., Fontaine, P., 2012. Levels of domestication in fish: implications for the sustainable future of aquaculture. Fish Fish, n/a.

Tobin, D., Kause, A., Mantysaari, E.A., Martin, S.A.M., Houlihan, D.F., Dobly, A., Kiessling, A., Rungruangsak-Torrissen, K., Ritola, O., Ruohonen, K., 2006. Fat or lean? The quantitative genetic basis for selection strategies of muscle and body composition traits in breeding schemes of rainbow trout (Oncorhynchus mykiss). Aquaculture 261, 510-521

Vandeputte, M., 2003. Selective breeding of quantitative traits in the common carp (Cyprinus carpio L.): a review. Aquat. Living Resour. 16, 399-407.

Vandeputte, M., Mauger, S., Dupont-Nivet, M., 2006. An evaluation of allowing for mismatches as a way to manage genotyping errors in parentage assignment by exclusion. Mol. Ecol. Notes 6, 265267.

Vandeputte, M., Dupont-Nivet, M., Haffray, P., Chavanne, H., Cenadelli, S., Parati, K., Vidal, M.O., Vergnet, A., Chatain, B., 2009. Response to domestication and selection for growth in the European sea bass (Dicentrarchus labrax) in separate and mixed tanks. Aquaculture 286, 20-27.

Wohlfarth, G.W., 1993. Heterosis for growth rate in common carp. Aquaculture 113, 31-46. 